\title{
Later Comes Earlier, Nowadays
}

While we deliberate about beginning, it is already too late to begin.

\section{Quintilian, 35-96 BCE}

We all agree that early identification and treatment of rheumatoid arthritis (RA) with "tight" control currently provide us our best opportunities to optimize outcomes for patients $1,2,3,4,5,6,7,8,9,10,11$. At present we seek drug-induced suppression of disease for prevention of inflammatory damage and consequent disability. We expect remissions in half or more patients we are able to treat early. We hope an occasional patient will retain a remission when drugs are tapered and even stopped. We are thrilled to have at least 9 conventional and 9 biological disease-modifying antirheumatic drugs (DMARD) to choose from and combine. However, we are frustrated that we do not have better markers to allow us to select the best therapy for each patient without the trial-and-error process we now utilize. We are disappointed and saddened when treatments fail, and patients suffer rather than benefit from therapy, as still happens. We struggle, too often unsuccessfully, to provide expensive state-of-the-art medications to all we think should receive them.

Early recognition and intervention for RA is one of the triumphs of an age of rheumatology that has truly transformed how we think about caring for patients. There is now urgency in finding RA patients and getting them to rheumatologists or comparable therapeutic programs. We now have new criteria that facilitate early classification of $\mathrm{RA}^{12}$. The 2010 revised classification criteria provide a framework to identify patients before the progression of disease (by eliminating the requirement of at least 6 weeks of disease or presence of nodules or erosions, and by focusing on the number and site of the involved joints, serologic abnormalities, acute-phase reactants, and symptom duration). Moreover, we have new tools available to quantifiably and reproducibly document the outcomes of our care ${ }^{13}$. These include Disease Activity Score 28 and other composite indices, acute-phase reactants, swollen and tender joint counts, physician and patient global assessments, and the potential use of musculoskeletal magnetic resonance imaging and ultrasound. While each has advantages and disadvantages, their thoughtful use ensures proper monitoring. Indeed, using an objective instrument to assess disease activity is superior to previous conventional and often subjective methods for making clinical decisions. Such tools are still underutilized in current practice. However, this may change as insurers, including the government, increasingly require them for quality assurance, and as practitioners appreciate their importance. And finally, we have a strict definition of disease remission. This reflects the tender and swollen joint count, C-reactive protein level, patient global assessment score, and the simplified Disease Activity Score ${ }^{14}$. Disease control is possible in early RA with the use of conventional DMARD ${ }^{3,4,5,6}$ and with the additional use of biologic anti-tumor necrosis factor agents ${ }^{7}$. Not only has combination therapy been found to be effective, but early, intensive treatment with monthly visits is considered superior to quarterly visits ${ }^{6}$. These changes, slowly percolating into daily practice, are the new paradigm for how we perceive RA and its optimal management.

Why can't we implement this universally now? What must we still know? Or do? The problems are procedural and perhaps also philosophical or even existential. When does disease begin ${ }^{15,16}$ ? When exactly is the benefit of early, aggressive treatment lost? What shall we do with individuals without clinical detectable disease who are seropositive for rheumatoid factor or cyclic citrullinated peptides? Is "RA" an oversimplification or a group of heterogeneous syndromes? Are there multiple "RAs"? And, when we decide it's time to intervene, what is best? For how long? What will be the most effective yet safest regimen?

There are potentially rather daunting procedural, logistical, practical, and societal problems too. Some of these are reported by Tavares, et al in this issue of The Journal; they provide valuable insights ${ }^{17}$. For example, the Canadian experience reported that from 2001 to $2003,91 \%$ of patients were started on DMARD therapy within 3 months of the recognition - not onset - of RA. These retrospective data did not mention use of biologic therapies, and infrequently included objective, standardized instruments measuring disease activity. Despite these limitations, these investigators provided a valuable glimpse into the clinical practice of treating early RA in the setting of socialized medicine. Further studies expanding on these preliminary results would certainly be of interest, offering a mirror to others highlighting achievements and failures in practice.

We need to do better. How does a society or community screen a population to find these patients? Absent screening, how is referral information disseminated effectively to primary care providers who would otherwise see these

See Early management of newly diagnosed RA, page 2342

Personal non-commercial use only. The Journal of Rheumatology Copyright @ 2011 . All rights reserved. 
patients serendipitously? How do we ensure an adequate number of rheumatologists to promptly accommodate referrals? If we rheumatologists can't do this, are there others who can? Or who can be trained? Unfortunately, we interpret available data as not supporting the notion that nonrheumatologists can do this ${ }^{18,19}$. And how do we ensure universal access to care? To costly contemporary therapies?

Our own respective experiences illustrate and in part contrast the problems we face and the successes we can achieve. One of us (KDT) with colleagues developed an initiative to provide longterm care for patients with RA in a primarily underserved, immigrant, uninsured, and often transient urban population, at the Rheumatology Clinics of the Los Angeles County (LAC+USC Medical Center) healthcare system, one of the country's largest public systems. This program demonstrates certain challenges in making the benefits of timely, appropriate care available to this patient population (Torralba KD, unpublished observations). In a system where demand for care often exceeds the supply of providers and other resources, patients recognized by their referring physician as having inflammatory arthritis may wait as long as 6 to 12 months before their first general rheumatologic evaluation, usually taking only nonsteroidal antiinflammatory drugs or corticosteroids. Recognition of this problem spurred us to develop an "early RA clinic" in 2008. Once seen by our team, aggressive DMARD therapy is instituted (within budgetary and formulary limits) to control disease as "tightly" as possible by following patients, with appropriate quantifiable metrics, monthly. Although we have not yet calculated health costs to patients and society stemming from their disability and the limitations of our healthcare system to initiate care for them sooner, we believe these to be significant. Patients arguably suffer unnecessary disability, have impaired quality of life, may not be able to work, and they may consume medications and other supportive resources, all subsidized by public funds. Surely this is not tolerated for certain other patients, like those with heart disease or stroke. We must better educate those in leadership: it is cost-effective and socially responsible, if not morally imperative, to do no less for our patients with chronic rheumatic disease.

Another of us (JRO) with colleagues had a different experience, having identified, enrolled in a clinical trial, and begun "disease-modifying" treatment in RA patients (with medications provided by sponsors) within a mean of less than 4 months of onset of symptoms of disease; a consortium of dozens of academic and private practices, the group included at least some indigent patients ${ }^{20}$. In a recently completed trial, both "triple therapy" (methotrexate, sulfasalazine, and hydroxychloroquine) and methotrexate plus etanercept were equally effective disease suppressants during the first year of therapy. Key to successfully identifying patients and starting them on medication early was the care of committed, available rheumatologists who strongly believe in early therapy and enrollment requirements of the trial, established collaborative relationships with primary care physicians, and the resources necessary to offer such care to patients.

These preliminary findings, together with the experience of our colleagues in Canada ${ }^{17}$, emphasize that prompt, aggressive utilization of conventional, effective, and affordable treatments offers all patients with RA opportunities to achieve full remission early in disease. This is the challenge of clinical practice.

Thus we near a threshold. We are able to control disease activity in the majority of patients with RA and prevent longterm disability if we can find patients with RA at onset of disease, start them on a therapeutic regimen, and reliably measure outcomes. The limitations we face are neither our current art nor science, but rather a lack of communal resources and will. It should be possible; at the very least we can do better. We owe it to our patients.

There are two mistakes one can make along the road to truth... not going all the way and not starting.

Gautama Sikkharta, 563-483 BCE

ELIZABETH C. ORTIZ, $M D$,

Assistant Professor;

KARINA D. TORRALBA, MD,

Assistant Professor,

Division of Rheumatology,

Department of Medicine,

Keck School of Medicine,

University of Southern California;

JAMES R. O'DELL, MD,

Bruce Professor of Medicine,

Chief, Division of Rheumatology,

Vice-Chair, Department of Internal Medicine,

University of Nebraska Medical Center,

and the Veterans Administration Medical Center,

Omaha, Nebraska;

RICHARD S. PANUSH, MD, MACP, MACR, Professor, Division of Rheumatology,

Department of Medicine,

Keck School of Medicine,

University of Southern California,

Los Angeles, California, USA

Address correspondence to Dr.Panush.E-mail: panush@usc.edu

\section{REFERENCES}

1. Verstappen SMM, Jacobs JWG, van der Veen MJ, Heurkens AHM, Schenk Y, ter Borg EJ, et al. Intensive treatment with methotrexate in early rheumatoid arthritis: Aiming for remission. Computer assisted management in early rheumatoid arthritis (CAMERA, an open-label strategy trial). Ann Rheum Dis 2007;66:1443-9.

2. Möttönen T, Hannonen P, Leirisalo-Repo M, Nissilä M, Kautiainen $\mathrm{H}$, Korpela M, et al. Comparison of combination therapy with single-drug therapy in early rheumatoid arthritis: A randomised trial. Lancet 1999;353:1568-73.

3. Korpela M, Laasonen L, Hannonen P, Kautiainen H, Leirisalo-Repo Personal non-commercial use only. The Journal of Rheumatology Copyright @ 2011 . All rights reserved. 
M, Hakala M, et al. Retardation of joint damage in patients with early rheumatoid arthritis by initial aggressive treatment with disease-modifying antirheumatic drugs: Five-year experience from the FIN-RACo study. Arthritis Rheum 2004;50:2072-81.

4. Soubrier M, Lukas C, Sibilia J, Fautrel B, Roux F, Gossec L, et al. Disease Activity Score-driven therapy versus routine care in patients with recent-onset active rheumatoid arthritis: Data from the GUEPARD trial and ESPOIR cohort. Ann Rheum Dis 2011; 70:611-5.

5. Goekoop-Ruiterman YP, de Vries-Bouwstra JK, Allaart CF, van Zeben D, Kerstens PJ, Hazes JM, et al. Clinical and radiographic outcomes of four different treatment strategies in patients with early rheumatoid arthritis (the BeSt study): A randomized, controlled trial. Arthritis Rheum 2005;52:3381-90.

6. Grigor C, Capell H, Stirling A, McMahon AD, Lock P, Vallance R, et al. Effect of a treatment strategy of tight control for rheumatoid arthritis (the TICORA study): A single-blind randomised controlled trial. Lancet 2004;364:263-9.

7. Van Vollenhoven RF, Ernestam S, Geborek P, Petersson IF, Coster L, Wattbrand E, et al. Addition of infliximab compared with addition of sulfasalazine and hydroxychloroquine to methotrexate in patients with early rheumatoid arthritis (Swefot trial): 1 year results of a randomized trial. Lancet 2009;374:459-66.

8. van Dongen H, van Aken J, Lard LR, Visser K, Ronday HK, Hulsmans HM, et al. Efficacy of methotrexate treatment in patients with probable rheumatoid arthritis: A double-blind, randomized, placebo-controlled trial. Arthritis Rheum 2007;56:1424-32.

9. Verstappen SMM, McCoy MJ, Roberts C, Dale NE, Hassell AB, Symmons DP, et al. Beneficial effects of a 3-week course of intramuscular glucocorticoid injections in patients with very early inflammatory polyarthritis: Results of the STIVEA trial. Ann Rheum Dis 2010;69:503-9.

10. Smolen JS, Aletaha D, Bijlsma JW, Breedveld FC, Boumpas D, Burmester G, et al. Treating rheumatoid arthritis to target: Recommendations of an international task force. Ann Rheum Dis 2010;69:631-7.

11. Scire CA, Verstappen SMM, Mirjafari H, Bunn DK, Lunt M, Montecucco C, et al. Reduction of long-term disability in inflammatory polyarthritis by early and persistent suppression of joint inflammation: Results from the Norfolk Arthritis Register. Arthritis Care Res 2011;63:945-52.
12. Aletaha D, Neogi T, Silman AJ, Funovits J, Felson DT, Bingham CO 3rd, et al. 2010 rheumatoid arthritis classification criteria. An American College of Rheumatology/European League Against Rheumatism collaborative initiative. Arthritis Rheum 2010;62:2569-81.

13. Aletaha D, Landewe R, Karonitsch T, Bathon J, Boers M, Bombardier C, et al. Reporting disease activity in clinical trials of patients with rheumatoid arthritis: EULAR/ACR collaborative recommendations. Arthritis Rheum 2008;59:1371-7.

14. Felson DT, Smolen JS, Wells G, Zhang B, van Tuyl LH, Funovits J, et al. American College of Rheumatology/European League Against Rheumatism provisional definition of remission in rheumatoid arthritis for clinical trials. Arthritis Rheum 2011;63:573-86.

15. Lefèvre S, Knedla A, Tennie C, Kampmann A, Wunrau C, Dinser $\mathrm{R}$, et al. Synovial fibroblasts spread arthritis to unaffected joints. Nat Med 2009;15:1414-20.

16. van de Sande MG, de Hair MJ, van der Leij C, Klarenbeek PL, Bos WH, Smith MD, et al. Different stages of rheumatoid arthritis: Features of the synovium in the preclinical phase. Ann Rheum Dis 2011;70:772-7.

17. Tavares R, Pope J, Tremblay J-C, Thorne C, Bykerk VP, Lazovskis $\mathrm{J}$, et al. Early management of newly diagnosed rheumatoid arthritis by Canadian rheumatologists: A national, multicenter retrospective cohort. J Rheumatol 2011;38:2342-5.

18. Panush RS, Kaplan H. Who will care for our patients? J Rheumatol 1995;22:2197-8.

19. Bernstein J, King T, Lawry RV. Musculoskeletal medicine educational reform in the bone and joint decade. Arthritis Rheum 2007;57:1109-11.

20. Moreland LW, O'Dell JR, Paulus H, Curtis JR, Bridges SL Jr, Zhang X, et al. TEAR: Treatment of early aggressive RA: a randomized double-blind, 2-year trial comparing immediate triple DMARD versus MTX plus etanercept to step-up from initial MTX monotherapy [abstract]. Arthritis Rheum 2009;60 Suppl:1895.

J Rheumatol 2011;38:2287-9; doi:10.3899/jrheum.111130. 